\title{
SOSIALISASI PEMANFAATAN SENYAWA BIOAKTIF DARI MIKROALGA DIATOM DALAM PRAKTIK BUDIDAYA PERIKANAN BERKELANJUTAN DI KABUPATEN INDRAMAYU
}

\author{
Sunarto ${ }^{1}$ Eri Bachtiar ${ }^{1}$, dan Fiddy Semba Prasetiya ${ }^{1,2}$ \\ ${ }^{1}$ Departemen Kelautan, Fakultas Perikanan dan Ilmu Kelautan, Universitas Padjadjaran \\ ${ }^{2}$ Pusat Riset Bioteknologi Molekuler dan Bioinformatika, Universitas Padjadjaran \\ E-mail: fiddy.semba.prasetiya@unpad.ac.id
}

\begin{abstract}
ABSTRAK. Mikroalga diatom dianggap sebagai organisme hidup yang memiliki banyak manfaat dan telah menarik banyak perhatian dari peneliti-peneliti dunia. Dalam beberapa tahun ini, diatom juga telah digunakan sebagai bahan nutrasetikal dan sumber obat dalam industri farmasi. Penduduk lokal di Desa Pabean Udik, Kabupaten Indramayu, sebagian besar memiliki profesi sebagai nelayan pembudidaya, dimana produksi perikanan budidaya berkontribusi cukup besar pada pendapatan daerah. Namun, salah satu kendala yang dialami oleh pembudidaya adalah adanya serangan penyakit yang disebabkan oleh bakteri patogen yang seringkali diatasi dengan penggunaan antibiotik sintetik yang tidak ramah lingkungan. Oleh karena itu, dalam penelitian ini, kami melakukan sosialisasi terhadap peningkatan kesadaran masyarakat lokal di Desa Pabean Udik tentang potensi diatom sebagai produk alami dengan multi-manfaat, terutama sebagai agen antibakteri alami dalam praktik budidaya perikanan laut. Dalam studi ini, pendidikan berbasis masyarakat dengan beberapa kegiatan seperti ceramah, diskusi, video interaktif dan sesi doorprize dilakukan. Selain itu, kuesioner pre-test dan post-test dilakukan sebagai alat untuk mengidentifikasi kesadaran peserta dan untuk mengukur indikator tujuan. Hasil survey yang diperoleh menunjukkan peningkatan pemahaman peserta hingga $20 \%$. Kami mengamati bahwa selama diskusi peserta juga menunjukkan kesediaan mereka untuk meningkatkan pengetahuan mereka tentang potensi pemanfaatan diatom untuk meminimalkan risiko infeksi patogen. Oleh karena itu, hasil ini menunjukkan bahwa penelitian ini berhasil meningkatkan pemahaman masyarakat lokal tentang potensi manfaat diatom dan meningkatkan kesadaran masyarakat untuk menggunakan diatom untuk banyak tujuan, terutama dalam menggantikan obat antimikroba yang tidak ramah lingkungan.
\end{abstract}

Kata kunci: mikroalga; diatom; agen antimikroba alami; desa Pabean Udik; peningkatan kesadaran masyarakat

ABSTRACT. Microalgae diatoms have been considered as living organisms that have multi-benefits and drawn many attentions from researchers worldwide. In recent years, have also been used as a nutritional ingredient and source of medicine in the pharmaceutical industry. Local residents in the village of Pabean Udik, Indramayu Regency, mostly have a profession as fishermen, where aquaculture production contributes significantly to regional income. However, disease outbreak caused by pathogenic bacteria has detrimental effect on production and mostly the fisherman overcome this problem by using synthetic anatibiotics that are not eco-friendly. Therefore, in the present study, we carried out a socialization program to increase awareness of local people in the village of Pabean Udik about the potential of diatoms as natural antibacterial agents in mariculture practice. In this study, community-based education with several activities such as lectures, discussions, interactive videos and doorprize session was conducted. Additionally, pre-test and post-test questionnaires were performed as a tool to identify the awareness of participants and to measure the goals indicators. The result showed augmentation of understanding of participants up to $20 \%$. We observed that during discussion participants showed their willingness to improve their knowledge on the potential utilization of algae to minimize the risk of pathogen infections. Therefore, these results suggest that the study successfully improve understanding of local people about the potential benefits of algae and raise public awareness to use algae for many purposes, especially in substituting the antimicrobial drugs that are not environmentally sustainable.

Key words: microalgae; diatoms; natural antimicrobial agents; Pabean Udik village; raising the awareness

\section{PENDAHULUAN}

Desa Pabean Udik merupakan sebuah desa yang berada di wilayah Kecamatan Indramayu, Kabupaten Indramayu, Jawa Barat. Desa ini terletak di sebelah Utara Pusat Kota Indramayu dengan batas desa yakni sebelah Utara Desa Brondong, Kecamatan Pasekan sebelah Selatan Kelurahan Paoman dan Desa Karangsong, Indramayu, Indramayu sebelah Timur Laut Jawa dan Desa Karangsong, Kecamatan Indramayu, Kabupaten Indramayu sebelah Barat Desa Pagirikan Kecamatan
Pasekan. Desa Pabean Udik terbentuk pada tahun 1982 dengan luas wilayah 545,932 Ha. Ketinggian tanah dari permukaan laut Desa Pabean Udik yaitu $0,5 \mathrm{~m}$, banyaknya curah hujan 2000 mm/thn. Desa Pabean Udik memiliki tofografi berbentuk dataran rendah, tinggi dan daerah pantai. Suhu udara rata-rata $39^{\circ} \mathrm{C}$.

Sumberdaya Perikanan di Kabupaten Indramayu sangat beragam. Kabupaten Indramayu merupakan kabupaten yang sebagian besar wilayahnya pesisir dan penduduknya bermatapencaharian sebagai nelayan. Hasil produksi laut dari Kabupaten Indramayu di jual 
keluar Indramayu khususnya kota-kota besar. Kegiatan perikanan di Kabupaten Indramayu ada delapan macam yaitu, kegiatan perikanan hasil tangkapan di laut, ikan hasil tangkapan diperairan umum, ikan hasil budidaya tambak, ikan hasil budidaya kolam, ikan hasil budidaya dilaut, pengolahan hasil perikanan dan kelautan, garam rakyat dan ikan hias. Menurut data dari Dinas Perikanan dan Kelautan Kabupaten Indramayu 2018, ikan hasil budidaya tambak memiliki jumlah Rumah Tangga Perikanan (RTP) terbesar dibandingkan dengan kegiatan perikanan lainnya, dengan nilai sebesar 2-3 milyar per tahun. Oleh karena itu, usaha pengembangan sektor budidaya perikanan harus dikelola dengan baik sehingga pemanfaatannya berkelanjutan.

Salah satu kendala yang dialami oleh pembudidaya adalah adanya serangan penyakit yang disebabkan oleh bakteri patogen, misalnya dari genus Vibrio (Kubanek et al., 2008; Lightner et al., 2014). Fenomena vibriosis yang disebabkan oleh bakteri Vibrio merupakan permasalahan yang besar yang seringkali dijumpai di sebagian besar kolam produksi budidaya udang (Kannapiran et al., 2009). Fenomena ini menyebabkan kematian pada hampir seluruh stadia pertumbuhan udang dengan tingkat kematian sebesar 100\% dari total populasi, sehingga diperlukan suatu upaya penanganan yang baik untuk mengatasi masalah pathogen (Sunaryanto dan Mariyam, 1987).

Konsep pemanfaatan mikroalga sebagai sumber bioaktiftelahmenjadipusat perhatian dalambeberapa tahun ini (Gastineau et al., 2014; Prasetiya et al., 2017; Prasetiya et al., 2019; Silkina et al., 2009; Vo et al., 2011). Namun potensi tersebut belum diketahui secara menyeluruh oleh masyarakat pesisir. Penggunaan antibiotik sintetik secara intensif cenderung sering dilakukan daripada penggunaan senyawa aktif yang bisa didapatkan dari mikroalga. Padahal cara ini tidak berkelanjutan karena dapat menyebabkan resistensi terhadap bakteri pathogen (Miranda \& Zemelman, 2002; Rico et al., 2013; Seyfried et al., 2010). Oleh karena itu, peningkatan kesadaran akan potensi mikroalga sebagai sumber antibakteri alami perlu dilakukan agar serangan patogen dapat dikurangi dan praktik budidaya bisa dilakukan secara berkelanjutan. Tujuan jangka panjang dari KKN PPM Departemen Kelautan Fakultas Perikanan dan Kelautan Unpad yaitu untuk mendukung mencapai tujuan pembangunan berkelanjutan (Sustainable Development Goals) sehingga dapat meningkatkan kesejahteraan masyarakat dengan tetap menjaga kelestarian lingkungan. Penelitian ini bertujuan untuk meningkatkan kesadaran masyarakat akan potensi senyawa-senyawa aktif dari mikroalga untuk budidaya perikanan. Hal ini bertujuan agar masyarakat juga sadar akan pentingnya penggunaan antibakteri alami dalam praktik budidaya untuk mengurangi fenomena resistensi bakteri patogen yang diakibatkan dari penggunaan antibakteri sintetik yang berlebihan.

\section{METODE}

Penelitian dilaksanakan dari bulan Juli hingga Agustus 2019, dengan lokasi penyuluhan bertempat di aula SMK Kelautan Pabean Udik, Desa Pabean Udik, Kabupaten Indramayu-Jawa Barat. Adapun peralatan penelitian yang digunakan untuk penyuluhan adalah kuesioner untuk melihat tingkat pengetahuan responden tentang alga, proyektor dan perangkat komputer untuk menayangkan video dan materi yang disampaikan, serta doorprice reward untuk games di akhir sesi diskusi, merujuk pada metode yang diterapkan oleh Setyawati et al. (2017) dan Wiraswati et al. (2018).

Subyek yang dilibatkan dalam penelitian ini adalah siswa SMK Pabean Udik yang tinggal di sekitar lokasi penelitian, dengan jumlah responden 35 orang. Kriteria inklusi subyek penelitian adalah pria dan wanita umur 15-18 tahun, berpendidikan minimal SD, dan terdaftar sebagai penduduk tetap di desa Pabean Udik minimal selama 10 tahun. Pelaksanaan penelitian ini telah disetujui oleh Tim peneliti Unpad dan juga Kepala Sekolah SMK Pabean Udik.

Dalam penelitian ini, bentuk kegiatan yang dilakukan berupa penyuluhan dengan menggunakan metode berbasis pendidikan masyarakat. Metode ini dilakukan dengan berbagai jenis aktivitas seperti ceramah, diskusi, pemutaran video dan juga tanya jawab berhadiah. Sebelum kegiatan penyuluhan dilakukan, peserta diminta untuk mengisi kuesioner pre-test untuk melihat pengetahuan awal peserta tentang algae. Setelah itu di awal penyuluhan, ditayangkan video tentang berbagai spesies alga untuk meningkatkan motivasi peserta sehingga mau mengetahui lebih jauh informasi tentang potensi dan manfaat alga di berbagai bidang. Setelah itu dilakukan penyampaian materi pertama tentang apa itu algae, yang kemudian dilanjutkan dengan penyampaian materi tentang beberapa contoh algae dan potensi manfaatnya di bidang kesehatan dan juga di bidang budidaya perikanan. Kemudian, sesi tanya jawab berhadiah dilakukan dengan menyampaikan beberapa pertanyaan terkait materi yang sudah disampaikan oleh pemateri. Setelah itu, peserta diminta untuk mengerjakan soal kuesioner on line yang digunakan sebagai post-test. Analisis dari hasil kuesioner dilakukan dengan menggunakan analisis deskriptif.

\section{HASIL DAN PEMBAHASAN}

Kegiatan penyuluhan berlangsung selama 2,5 jam yang terdiri dari 0,5 jam pertama merupakan waktu registrasi dan pembimbingan pengisian kuesioner awal dan akhir, 2 jam berikutnya merupakan inti penyuluhan berupa penyampaian materi dan games tanya jawab. Secara keseluruhan seluruh kegiatan penyuluhan berlangsung dengan tertib, aman dan lancar. Hal ini juga yang ditandai dengan tercapainya beberapa indikator diantaranya adalah sebagai berikut: 
1. Seluruh peserta penyuluhan hadir tepat waktu

2. Seluruh peserta penyuluhan mengikuti kegiatan dari awal hingga acara selesai

3. Pelaksanaan kegiatan berlangsung sesuai dengan agenda yang telah direncanakan

4. Penyampaian materi sesuai dengan rancangan pembelajaran yang telah dibuat

5. Peserta sangat aktif dalam mengikuti sesi diskusi dan tanya jawab berhadiah yang merupakan salah satu indikator ketercapaian penyampaian materi.

Beberapa faktor yang turut mempengaruhi baiknya respon positif masyarakat dalam mengikuti kegiatan penyuluhan ini adalah pertama, dukungan yang sangat baik dari aparat desa setempat, dalam hal ini diwakili oleh Kepala Desa, beserta perangkat desa lainnya seperti ketua RW dan RT di Desa Pabean Udik serta Kepala Sekolah beserta guru-guru SMK Pabean Udik. Kepala Desa menghimbau kepada semua peserta agar mengikuti kegiatan dari awal sampai akhir. Selain itu, beliau juga berharap agar kegiatan pengabdian masyarakat seperti ini bisa berlangsung secara berkelanjutan karena program seperti ini belum pernah dilakukan di Desa Pabean Udik. Kedua, kerjasama yang baik dari mitra yaitu Pengurus Yayasan SMK Kelautan Pabean Udik yang telah membangun komunikasi yang baik dengan pihak aparat desa. Pengurus yayasan juga menyampaikan penjelasan pendahuluan tentang penelitian yang dilakukan oleh tim peneliti baik kepada aparat desa maupun calon peserta sehingga secara teknis memudahkan pelaksanaan pada saat kegiatan penyuluhan dilakukan. Pengurus yayasan juga memberikan dukungan yang sangat baik kepada tim peneliti dengan menyediakan berbagai sarana (gedung, auditorium, dll) dan prasarana (proyektor, peralatan sound system, dil) yang dibutuhkan selama penyuluhan. Ketiga, jenis aktivitas yang bervariasi dan tidak monoton dengan melibatkan peserta dalam proses penyampaian materi, membuat para peserta merasa nyaman dan termotivasi dalam mengikuti proses penyuluhan dari awal sampai akhir kegiatan. Sistematisnya rancangan dari seluruh rangkaian kegiatan penyuluhan dalam satu modul pembelajaran lengkap juga merupakan salah satu faktor yang mendukung kelancaran kegiatan sosialisasi ini.

\section{Peningkatan tingkat pengetahuan peserta tentang diatom, potensi dan manfaatnya}

Perubahan tingkat pemahaman peserta tentang potensi pemanfaatan diatom dalam praktik budidaya berkelanjutan ditentukan dari total 35 peserta yang hadir. Perubahan tingkat pengetahuan peserta tentang kanker diukur dengan membandingkan hasil post-test dan pre-test (sebelum dan sesudah kegiatan sosialisasi). Skor kuesioner pada pre-test berada pada rentang 23\%-73\% dengan pemahaman rata-rata sebelum penyuluhan sebesar $46 \%$. Hasil ini mengalami kenaikan setelah dilakukan pengayaan materi dengan skor post-test berada pada rentang 34\%-
$89 \%$ dengan pemahaman rata-rata setelah penyuluhan sebesar 69\%. Dari hasil tersebut maka dapat diasumsikan bahwa metode yang dilakukan pada penelitian ini berhasil meningkatkan pemahaman rata-rata $23 \%$ bagi peserta. Peningkatan pemahaman paling kecil terjadi pada peserta dengan kode responden 11 dan 22 dengan kenaikan pemahaman sebesar 5 dan $6 \%$. Sementara itu, peningkatan pemahaman tertinggi terjadi pada peserta dengan kode 34 dengan kenaikan pemahaman sebesar 55\%. Hasil studi yang diperoleh menunjukkan bahwa metode yang digunakan dalam kegiatan sosialisasi ini cukup efektif untuk meningkatan pemahaman peserta tentang diatom dan potensi serta pemanfaatannya khususnya dalam praktik budidaya perikanan yang berkelanjutan dan ramah lingkungan.

Peningkatan pemahaman peserta terkait diatom dan pemanfaatannya didukung juga dengan partisipasi peserta selama sesi diskusi yang menunjukkan adanya kesadaran akan potensi pemanfaatan diatom pada kegiatan budidaya perikanan ramah lingkungan. Hal ini juga didukung oleh hasil post-test yang mengukur aspek afektif peserta, dimana peserta menyatakan akan menyebarkan pengetahuan yang sudah mereka peroleh selama kegiatan sosialisasi kepada orang lain khususnya mitra nelayan pembudidaya.

\section{SIMPULAN}

Kegiatan sosialisasi tentang pemanfaatan senyawa aktif dari mikroalga diatom dalam praktik budidaya perikanan berkelanjutan di SMK Pabean Udik, Desa Pabean Udik, Kabupaten Indramayu berjalan dengan lancar. Antusiasme dari peserta kegiatan sosialisasi terlihat cukup tinggi yang ditandai dengan partisipasi aktif dari para peserta ketika menerima materi selama kegiatan berlangsung dan juga pada saat sesi diskusi. Pengamatan ini juga didukung oleh feedback kuesioner dari para peserta dimana kegiatan sosialisasi ini berhasil meningkatkan pemahaman rata-rata peserta sebesar $46 \%$ dengan rentang pemahaman yang berkisar antara 23\%-73\%. Hasil penelitian ini diharapkan dapat menjadi langkah awal untuk mengubah persepsi masyarakat lokal khususnya nelayan pembudidaya, dalam upaya pemanfaatan diatom sebagai sumber antipatogen alami dalam praktik budidaya berkelanjutan di Kabupaten Indramayu.

\section{UCAPAN TERIMAKASIH}

Penulis menyampaikan terima kasih kepada Direktorat Riset, Pengabdian Kepada Masyarakat dan Inovasi (DRPMI) Universitas Padjadjaran yang telah mendanai penelitian ini. Ucapan terima kasih juga penulis sampaikan kepada yayasan SMK Kelautan Pabean Udik, Aparatur Desa Pabean Udik, dan tokoh-tokoh masyarakat Desa Pabean Udik yang telah menjadi mitra yang membantu kelancaran penelitian ini. 


\section{DAFTAR PUSTAKA}

Gastineau, R., Turcotte, F., Pouvreau, J.-B., Morançais, M., Fleurence, J., Windarto, E., ... Mouget, J.-L. (2014). Marennine, promising blue pigments from a widespread Haslea diatom species complex. Marine Drugs, 12(6), 3161-3189.

Kannapiran, E., Ravindran, J., Chandrasekar, R., \& Kalaiarasi, A. (2009). Studies on luminous, Vibrio harveyi associated with shrimp culture system rearing Penaeus monodon. Journal of Environmental Biology, 30(5 SUPPL.), 791-795.

Miranda, C. D., \& Zemelman, R. (2002). Antimicrobial multiresistance in bacteria isolated from freshwater Chilean salmon farms. Science of the Total Environment, 293(1-3), 207-218.

Prasetiya, F. S., Decottignies, P., Barillé, L., Gastineau, R., Jacquette, B., Figiel, A., ... Cognie, B. (2017). Cell size-based, passive selection of the blue diatom Haslea ostrearia by the oyster Crassostrea gigas. Journal of Molluscan Studies, 1-8.

Prasetiya, F. S., Gastineau, R., Poulin, M., Lemieux, C., Turmel, M., Syakti, A. D., ... Leignel, V. (2019). Haslea nusantara (Bacillariophyceae), a new blue diatom from the Java Sea, Indonesia: morphology, biometry and molecular characterization. Plant Ecology and Evolution, 151(2), 188-202.

Prince, E. K., Myers, T. L., Naar, J., \& Kubanek, J. (2008). Competing phytoplankton undermines allelopathy of a bloom-forming dinoflagellate. Proceedings. Biological Sciences / The Royal Society, 275(1652), 2733-2741.

Rico, A., Phu, T. M., Satapornvanit, K., Min, J., Shahabuddin, a. M., Henriksson, P. J. G., ...
Van den Brink, P. J. (2013). Use of veterinary medicines, feed additives and probiotics in four major internationally traded aquaculture species farmed in Asia. Aquaculture, 412-413, 231-243.

Setyawati, A., Harun, H., Herliani, K., \& Gerrish, M. (2017). Peningkatan pengetahuan perawat dan bidan tentang. Dharmakarya, 6(1), 53-56.

Seyfried, E. E., Newton, R. J., Rubert, K. F., Pedersen, J. a., \& McMahon, K. D. (2010). Occurrence of tetracycline resistance genes in aquaculture facilities with varying use of oxytetracycline. Microbial Ecology, 59(4), 799-807.

Silkina, A., Bazes, A., Vouvé, F., Le Tilly, V., Douzenel, P., Mouget, J. L., \& Bourgougnon, N. (2009). Antifouling activity of macroalgal extracts on Fragilaria pinnata (Bacillariophyceae): A comparison with Diuron. Aquatic Toxicology, 94(4), 245-254.

Tran, Loc H., Ftizsimmons, Kevin M., Lightner, D. V. (2014). Tilapia could enhance water conditions, help control EMS in shrimp ponds. Global Aquaculture Advocate, (January), 11-12.

Vo, T.-S., Ngo, D.-H., Ta, Q. Van, \& Kim, S.-K. (2011). Marine organisms as a therapeutic source against herpes simplex virus infection. European Journal of Pharmaceutical Sciences: Official Journal of the European Federation for Pharmaceutical Sciences, 44(1-2), 11-20.

Wiraswati, H. L., Ekawardhani, S., Windria, S., Faridah, L., Saragih, S., Arif, M. S. B. S., ... Raidah, S. N. (2018). Peningkatan Pengetahuan Kanker Payudara Pada Masyarakat Desa Rancamanyar Kabupaten Bandung. Dharmakarya, 7(4), 261264. 